\title{
密度噴流の拡散に寄与する波の効果 MODELING THE EFFECTS OF WAVE ON MIXING ENHANCEMENT OF SUBMERGED BUOYANT JETS
}

\author{
楊 宏選 1 早川典生 2 \\ Hongxuan YANG and Norio HAYAKAWA

\begin{abstract}
1正会員 工修 長岡技術科学大学 環境建設系 (
\end{abstract} \\ 2フェロー会員 Ph.D 長岡技術科学大学 環境建設系（广940-2188 新潟県長岡市上富岡町 1603-1)
}

\begin{abstract}
A Lagrangian model is developed for predicting a turbulent buoyant jet discharged into wave-induced flow environments. Two entrainment coefficients are involved in the model: one describing the shear entrainment identical with that of traditional models for jets into stagnant ambient fluids while the other describing the forced entrainment due to wave-induced velocity assumed as constant herein. Model predictions are compared with experiments of buoyant jets into ambient water with shallow water wave conditions, and the agreement is very good. The present model is also validated for the limited case of zero ambient velocity. It is revealed that the waves may significantly increase the dilution achieved by the ocean outfalls. Taking into account of the wave effects on the jet mixing would make the outfall design easy to satisfy the environmental standard with lower costs than otherwise.
\end{abstract}

Key Words: dilution, buoyant jet, shallow water wave, shear entrainment, forced entrainment

\section{1. 序論}

都市廃水や発電所冷却水の海洋への放流は典型的 な密度噴流である．水質保全や環境アセスメントの 需要から密度噴流の研究は半世紀前まで遡ることが できる。一般的に, 静止流体環境への水中密度噴流 に比べて, 流れる流体環境への水中密度噴流の方が 乱流混合が強く, 濃度の減衰はより速くなる. 静止 流体環境への放流はもとより, 密度成層した流体環 境, および定常な流れ場に垂直に噴出される水中密 度噴流は多くの研究者に研究されてきて実用に耐え るほどの解析モデルも多数提案されている ${ }^{1,2,2,3,4), 5)}$. これらの解析モデルは実験デー夕に基づき最適解を 得るようにとモデル中の係数を決めている。しかし， フィールド測定から希釈度 (di lut ion)の実測值は解 析モデルの予測值より高いことが示されている6),7). これは污水や温水の沿岸水域における海中放流は常 に潮汐および波の影響を受けるので，こうした変動 流れの密度噴流拡散に与える影響をモデルに取り入 れていないのが一因であると考えられる。

波または潮流を想定した規則的に変動する流れ場 に放出する密度噴流の研究は少ないものの, いくつ か行われている8),9),10),11),12). Chin $^{11)}$ のパイ定理を適用
した次元解析によれば，密度噴流が水面に浮上した 時の希釈度 $\mathrm{S}$ は $\mathrm{S}=f\left(\mathrm{H} / \mathrm{L}_{\mathrm{M}}, \mathrm{L}_{\mathrm{M}} / \mathrm{L}_{\mathrm{Q}}, \mathrm{L}_{\mathrm{m}} / \mathrm{L}_{\mathrm{Q}}, \mathrm{h} / \mathrm{L}, \boldsymbol{\beta}, \boldsymbol{\alpha}\right)$ である (図-1).ここにH：排水口の水深, $\mathrm{h}$ ：水深, $\mathrm{L}$ ：波 長, $\beta$ : 放流方向と水平面のなす角, $\alpha$ : 放流方向と 波進行方向のなす角である．長さスケール $\mathrm{L}_{\mathrm{M}}, \mathrm{L}_{\mathrm{Q}}$ と $\mathrm{L}_{\mathrm{m}}$ は, 体積フラックス $\mathrm{Q}=\mathrm{AU}_{0}$, 運動量フラックス $\mathrm{M}=\mathrm{QU}_{0}$, 浮力フラックス $\mathrm{B}=\mathrm{Qg} \Delta \rho_{0} / \rho_{0}$, および波が排

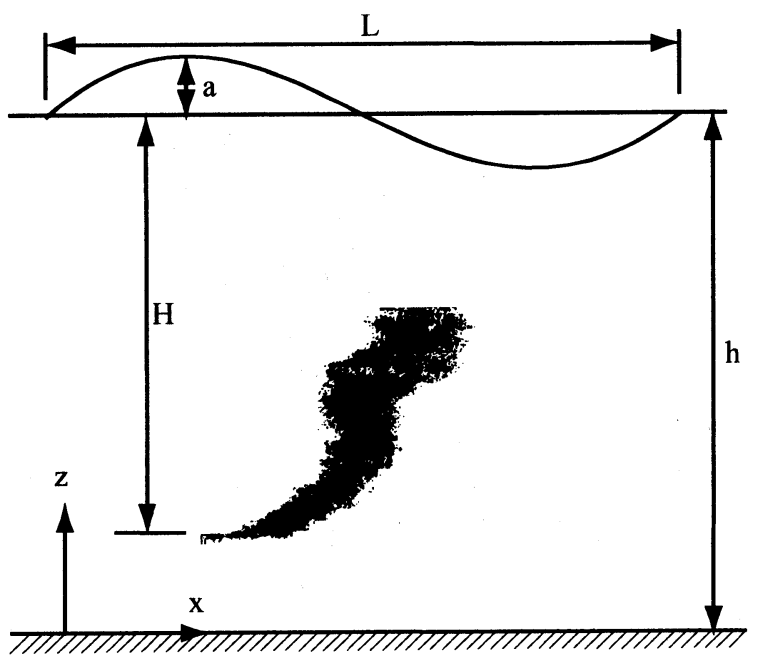

図一１波環境における水中密度噴流 


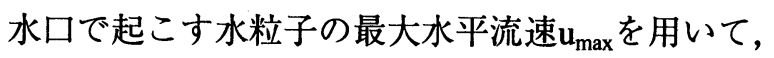
それぞれ $\mathrm{L}_{\mathrm{Q}}=\mathrm{Q} / \mathrm{M}^{1 / 2}, \mathrm{~L}_{\mathrm{M}}=\mathrm{M}^{3 / 4} / \mathrm{B}^{1 / 2}, \mathrm{~L}_{\mathrm{m}}=\mathrm{M}^{1 / 2} / \mathrm{u}_{\max }$ と定 義される。ここにA：排水口面積, $\mathrm{U}_{0}$ : 放流速度, $\mathrm{g}$ : 重力加速度, $\Delta \rho_{0}$ : 密度噴流と周囲流体の初期密 度差, $\rho_{0}$ : 密度噴流の初期密度である. 長さスケー ルは密度噴流を特性づける際に便利なパラメータで, 多くの研究者に議論されている ${ }^{2), 13)}$. $\mathrm{L}_{\mathrm{Q}}$ は初期流量 $\mathrm{Q}$ が重要な働きを持つ長さ; $\mathrm{L}_{\mathrm{M}}$ は初期運動量が支配 的要素となる長さで, この長さを超えると浮力が支 配的となる; $\mathrm{L}_{\mathrm{m}}$ は密度噴流の流速が波の起こした流 速レベルに減衰するのに要する長さである． $\mathrm{L}_{\mathrm{m}} / \mathrm{L}_{\mathrm{Q}}$ は波効果を，h/Lは波形を表すパラメータである. 実際の海中放流の多〈は $\mathrm{L}_{\mathrm{M}}>>\mathrm{L}_{\mathrm{Q}}$ 且つ $\mathrm{H}>>\mathrm{L}_{\mathrm{M}}$ で, 希 釈度Sは主に放流の浮カフラックスに支配される2). Shuto \& $\mathrm{Ti}^{8}{ }^{8}$ は鉛直密度噴流に与える波の効果を研究 し，その実験は上記無次元パラメータで考えると $\mathrm{H} / \mathrm{L}_{\mathrm{M}}=0.66, \mathrm{~L}_{\mathrm{M}}>\mathrm{L}_{\mathrm{m}}>\mathrm{L}_{\mathrm{Q}}, \mathrm{h} / \mathrm{L}<0.5$ となり, 水深にわ たって波流速が一様で, 浮力効果は支配的要素では ない. 実験結果は $\mathrm{S}=8.23\left(\mathrm{~L}_{\mathrm{m}} / \mathrm{L}_{\mathrm{Q}}\right)\left(\mathrm{h} / \mathrm{L}_{\mathrm{M}}\right)^{2}$ で表されるが, $\mathrm{S}$ は $\left(\mathrm{L}_{\mathrm{m}} / \mathrm{L}_{\mathrm{Q}}\right)$ に比例するところに疑問点が残る ${ }^{11)}$. 波 高はゼロに減じた時, $\mathrm{L}_{\mathrm{m}} \rightarrow \infty$ から $\mathrm{S} \rightarrow \infty$ となってし まうからである. $\mathrm{Ger}^{9}{ }^{9}$ は水平密度噴流に与える波の 効果を研究し, その実験は $\mathrm{H} / \mathrm{L}_{\mathrm{M}}=0.29-2.1$, $\mathrm{L}_{\mathrm{M}} / \mathrm{L}_{\mathrm{Q}}=2.1-9.1, \mathrm{~L}_{\mathrm{m}} / \mathrm{L}_{\mathrm{Q}}=0.15-0.95, \mathrm{~h} / \mathrm{L}<0.07$ と特徴付 けられ，密度噴流は主に放流量と波流速に支配され， 波も長波に近い。これらの実験に比べ, $\mathrm{Chin}^{11)}$ は典 型的な海中放流環境を想定し, $\mathrm{H} / \mathrm{L}_{\mathrm{M}}=9, \mathrm{~L}_{\mathrm{M}} / \mathrm{L}_{\mathrm{Q}}=17$, $\mathrm{L}_{\mathrm{m}} / \mathrm{L}_{\mathrm{Q}}=7.4-31.3$ として波向に並行する水平密度噴流 の実験を行った. その実験で $\mathrm{H} / \mathrm{L}_{\mathrm{M}}, \mathrm{L}_{\mathrm{M}} / \mathrm{L}_{\mathrm{Q}}, \beta, \alpha$ は 固定値のため, 希釈度 $\mathrm{S} は \mathrm{~L}_{\mathrm{m}} / \mathrm{L}_{\mathrm{Q}}$ と $\mathrm{h} / \mathrm{L}$ に依存する。 実験結果からh/Lの影響はマイナーで, 希釈度 $\mathrm{S} は$ 主 に $\mathrm{L}_{\mathrm{m}} / \mathrm{L}_{\mathrm{Q}}$ によって決定される. Ismail \& Wiegel ${ }^{10}$ は波 進行方向に向かって放流される表層噴流の研究を行 い，実験およびスケール解析を通して，屈折による 波の運動量フラックスの作用で, 噴流の広がり幅は 波のない時に比べて大きいのを示した。楊と早川 ${ }^{12)}$ の変動流れを扱うモデルは, 定常解を初期条件とす るため, 周期の短い波環境に不適である.

このように密度噴流は, 波の存在によって, 幅の 広がり速度と濃度減衰が加速され, 波のない場合に 比べて, より大きい希釈効果が得られる. 波の効果 を考慮することで,より緩い設計で環境基準を満た すことができ, 放流施設コスト隇と環境アセスメン トに寄与することが期待できる。これには波の効果 を定性的に考慮するだけでは不十分で, 定量的に評 価することが要求される. 本研究は波の起こした流 速場をモデルに組み込み, 放流口から出る密度噴流 の流体塊をラグランジュ的に追跡することで噴流流 脈を特定し, 波の密度噴流に寄与する効果を定量化 することが目的である。

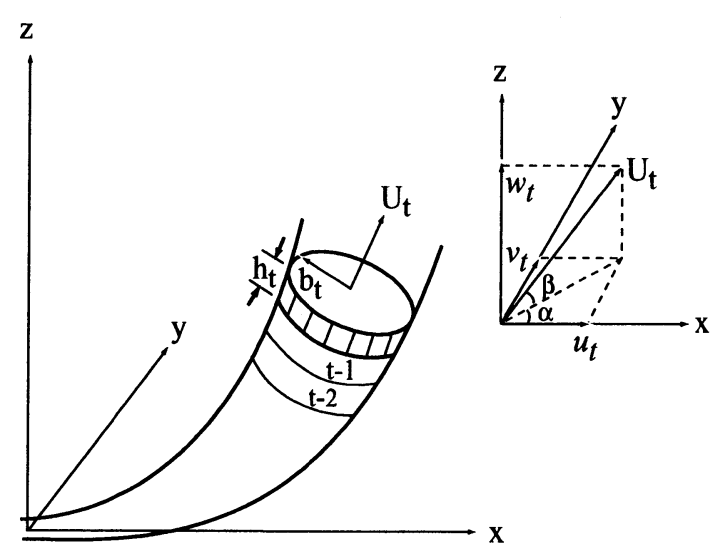

図一2 微小厚さの切片が一定時間内にたどった道筋

\section{2.ラングランジュモデル}

\section{（1）基本コンセプト}

本研究は定常流のラグランジュモデル ${ }^{3)}$ 非定常 流に拡張するものである。体積フラックス $\mathrm{Q}=\mathrm{AU}_{0}$, 運動量 フラックス $\mathrm{M}=\mathrm{QU}_{0}$, 浮カフラックス $\mathrm{B}=\mathrm{Qg} \Delta \rho_{0} / \rho_{0}$ の密度噴流が波環境に放出され, 放流流 速と水平面のなす角が $\beta$, 放流流速水平面投影と $\mathrm{x}$ 軸 のなす角が $\alpha$ とする. 周囲流体の変数に上付き小文 字aをつけて環境流体を表す。放流パラメータから 密度噴流の特性值(幅, 軌道, 流速, 希釈度)を予測 するのがモデルの目的である. 図一 2 にこのモデル のコンセプトを示す. 放流口から次々と出る噴流流 体の切片の運動に注目してその流跡(path line)を求め, ある時刻で各位置にある個々の切片をつなぐと, 流 脈(streak line)すなわち密度噴流軌道が得られる。切 片の諸元を流速 $\mathrm{U}(\mathrm{x}, \mathrm{y}, \mathrm{z}$ 方向成分は $\mathrm{u}, \mathrm{v}, \mathrm{w})$, トレー サーc(温度, 塩分濃度その他保存性スカラー), 密度 $\rho$, 断面積 $\mathrm{A}$ (円形とするなら $\mathrm{A}=\pi \mathrm{b}^{2}, \mathrm{~b}$ は半径), 厚さ $\mathrm{h}$, 体積 $\mathrm{V}(=\mathrm{Ah})$, 方向 $(\alpha, \beta)$, 位置 $(\mathrm{x}, \mathrm{y}, \mathrm{z})$ とし, 変動場 の流れは位置と時間で記述できるとする．切片位置 と時間から, 変動場の流れすなわち周囲流速 $\mathrm{U}_{\mathrm{a}}$ が決 まり, 次の微小時間 $\Delta \mathrm{t}$ の間 $\mathrm{U}_{\mathrm{a}}$ が変わらないと近似し, 切片の $\Delta \mathrm{t}$ 後の新しい位置, 流速などの諸元を求める. 時間増分 $\Delta \mathrm{t}$ をさくすればするほどこの近似は精度 が高くなる。

\section{(2) モデルの構築}

体積, 運動量, およびトレーサーの保存を考慮し $\tau$, 時刻 $\mathrm{t}$ 噴流流体切片の諸元から, 微小時間 $\Delta \mathrm{t}$ 後 の時刻 $\mathrm{t}+1$ の切片諸元を以下のような式で求める：

体積:

$$
V_{t+1}=V_{t}+\Delta V_{t}
$$

トレーサー： $\quad c_{t+1}=\left(c_{t} V_{t}+c_{t}^{a} \Delta V_{t}\right) / V_{t+1}$ 
密度：

$$
\rho_{t+1}=\rho\left(c_{t+1}\right)
$$

運動量：

$$
\begin{aligned}
& u_{t+1}=\frac{\left(u_{t} \rho_{t} V_{t}+u_{t}^{a} \rho_{t}^{a} \Delta V_{t}\right)}{\rho_{t+1} V_{t+1}} \\
& v_{t+1}=\frac{\left(v_{t} \rho_{t} V_{t}+v_{t}^{a} \rho_{t}^{a} \Delta V_{t}\right)}{\rho_{t+1} V_{t+1}} \\
& w_{t+1}=\frac{\left(w_{t} \rho_{t} V_{t}+w_{t}^{a} \rho_{t}^{a} \Delta V_{t}+V_{t} \Delta \rho_{t} g\right)}{\rho_{t+1} V_{t+1}}
\end{aligned}
$$

位置：

$$
\begin{aligned}
& x_{t+1}=x_{t}+u_{t} \Delta t \\
& y_{t+1}=y_{t}+v_{t} \Delta t \\
& z_{t+1}=z_{t}+w_{t} \Delta t
\end{aligned}
$$

面積と厚さ：

$$
\begin{aligned}
& h_{t+1}=\frac{\sqrt{u_{t+1}^{2}+v_{t+1}^{2}+w_{t+1}^{2}}}{\sqrt{u_{t}^{2}+v_{t}^{2}+w_{t}^{2}}} h_{t} \\
& A_{t+1}=V_{t+1} / h_{t+1}
\end{aligned}
$$

噴流方向：

$$
\begin{aligned}
& \cos \alpha_{t+1}=\frac{u_{t+1}}{\sqrt{u_{t+1}^{2}+v_{t+1}^{2}}} \\
& \sin \alpha_{t+1}=\frac{v_{t+1}}{\sqrt{u_{t+1}^{2}+v_{t+1}^{2}}} \\
& \sin \beta_{t+1}=\frac{w_{t+1}}{\sqrt{u_{t+1}^{2}+v_{t+1}^{2}+w_{t+1}^{2}}} \\
& \cos \beta_{t+1}=\frac{\sqrt{u_{t+1}^{2}+v_{t+1}^{2}}}{\sqrt{u_{t+1}^{2}+v_{t+1}^{2}+w_{t+1}^{2}}}
\end{aligned}
$$

保存式(1.1) (3.3)に現れる $\Delta \mathrm{V}$ は連行による流体切片 の体積増加分で, 噴流軸方向速度差 $\Delta \mathrm{U}(=\mid$ 噴流流速 $\mathrm{U}$-周囲流速の噴流軸方向流速成分 $\left.\mathrm{U}_{\mathrm{p}} \mathrm{a} \mid\right)$ のシアによる 連行(Shear Entrainment) $\Delta \mathrm{V}_{\mathrm{s}}$ と周囲流体の噴流に垂直 する流速成分 $\mathrm{U}_{\mathrm{n}}{ }^{\mathrm{a}}$ が噴流に衝突することによる連行 (Forced Entrainment) $\Delta \mathrm{V}_{\mathrm{f}}$ に分けられる， $\Delta \mathrm{V}_{\mathrm{s}}$ と $\Delta \mathrm{V}_{\mathrm{f}}$ は それぞれ次のように表される：

$$
\begin{aligned}
& \Delta V_{s}=2 \pi b h E_{s} \Delta U \Delta t \\
& \Delta V_{f}=2 b h E_{f}\left|U_{n}^{a}\right| \Delta t
\end{aligned}
$$

なお， $E_{s}$ と $E_{f}$ は連行係数，bは断面半径である．総連 行量は一般的に $\Delta \mathrm{V}=\Delta \mathrm{V}_{\mathrm{s}}+\Delta \mathrm{V}_{\mathrm{f}}$ で扱われる. $\Delta \mathrm{U}$ と $\Delta \rho$ の 分布をガウス分布, つまり

$$
\begin{aligned}
& \Delta U=\Delta U_{m} \exp \left(-r^{2} / b^{2}\right) \\
& \Delta \rho=\Delta \rho_{m} \exp \left[-r^{2} /\left(\lambda^{2} b^{2}\right)\right]
\end{aligned}
$$

と近似するのは一般的である。ここで入は乱流シュ ミット数，下付き文字 $\mathrm{m}$ は噴流中心の值を表す. $\mathrm{E}_{\mathrm{s}}$ はFan\&Brooks ${ }^{1)}$ とLee\&Cheng ${ }^{3)}$ の式を再構成し

$$
E_{s}=\operatorname{Max}\left(0.057+0.554 \operatorname{Sin} \beta / F^{2}, 0.085\right)
$$

で表すことができる. $\mathrm{F}=\left|\Delta \mathrm{U}_{\mathrm{m}}\right|\left(\mathrm{gb} \Delta \rho / \rho_{0}\right)^{1 / 2}$ はローカ ルフルード数である．環境流体が流速 $\mathrm{U}_{\mathrm{n}}{ }^{\mathrm{a}}$ ですべて 密度噴流に進入したと考えて， $\mathrm{E}_{f}$ は1と見積もられ
るが, 本研究は実験データにもっとも合うように $\mathrm{E}_{f}$ の最適值を求める。なお，式(9)は速度差 $\Delta U$ と密度

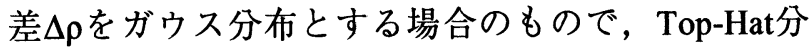
布とする場合，次の式で関連づけられる2),3)

$\mathrm{U}_{\mathrm{th}}=\mathrm{U}_{\mathrm{g}} / 2 ; \mathrm{b}_{\mathrm{th}}=2^{1 / 2} \mathrm{~b}_{\mathrm{g}} ; \Delta \rho_{\mathrm{th}}=\Delta \rho_{\mathrm{g}} \lambda^{2} /\left(1+\lambda^{2}\right) ; \mathrm{E}_{\mathrm{sth}}=2^{1 / 2} \mathrm{E}_{\mathrm{sg}}$ なお，下付き文字thとgはそれぞれTop-Hatとガウス 分布を表す。

\section{(3) オイラー型積分モデルとの関係}

式(2.1)〜(9)を使って, 流体切片が放流口を出る時 刻 $\mathrm{t}_{0}$ から水面に上昇した時刻 $\mathrm{t}_{\mathrm{s}}$ まで追跡計算すると, 時刻 $\mathrm{t}_{0}$ に放出される流体の流跡が求まる. $\Delta \mathrm{t} \rightarrow 0$ にし て上記式を微分形に書き直すと既存の定常環境にお けるオイラー型密度噴流モデルとの関連がわかりや すくなる：

$$
\begin{aligned}
& \frac{d}{U d t}(U A)=2 \pi b E_{s} \Delta U+2 b E_{f}\left|U_{n}^{a}\right| \\
& \frac{d}{U d t}(u U A)=u^{a} E \\
& \frac{d}{U d t}(v U A)=v^{a} E \\
& \frac{d}{U d t}(w U A)=w^{a} E+A \frac{\Delta \rho}{\rho_{0}} g \\
& \frac{d}{U d t}(\Delta \rho U A)=-(V A) \frac{d \rho^{a}}{d s} \\
& \frac{d x}{U d t}=\cos \alpha \cos \beta \\
& \frac{d y}{U d t}=\sin \alpha \cos \beta \\
& \frac{d z}{U d t}=\cos \beta
\end{aligned}
$$

この中にsは噴流流体切片の $\mathrm{t}_{0} \sim \mathrm{t}_{\mathrm{s}}$ までの流跡中心線 である。静止または定常流環境に噴出される密度噴 流は流跡と流脈が一致するので, 流跡sは密度噴流

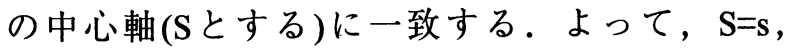
$\mathrm{dS}=\mathrm{Udt}$ が成立する。式(10)中のUdtを $\mathrm{dS}, \mathrm{s}$ を $\mathrm{S}$ 入 れ替えると, 定常環境の密度噴流の積分モデル に 本質的に一致することがわかる.

実際の流跡追跡に当たって, 離散形の式(2.1)〜(9) を使うより，微分形の式(10)を使った方が便利で, 精度も高い. これは常微分方程式の高次精度数值解 を得るための研究成果が多く，そのプログラムコー ドも広く普及しているためである。本研究は4次の ルンゲ・クッタ法で式(10)の数值解を求めている.

\section{3. モデルの評価と応用}

\section{（1）波の影響を受けない環境}

波の振幅がゼロ,つまり周囲流速がない静水環境 に放出される密度噴流は流脈と流跡が一致し, 流体 


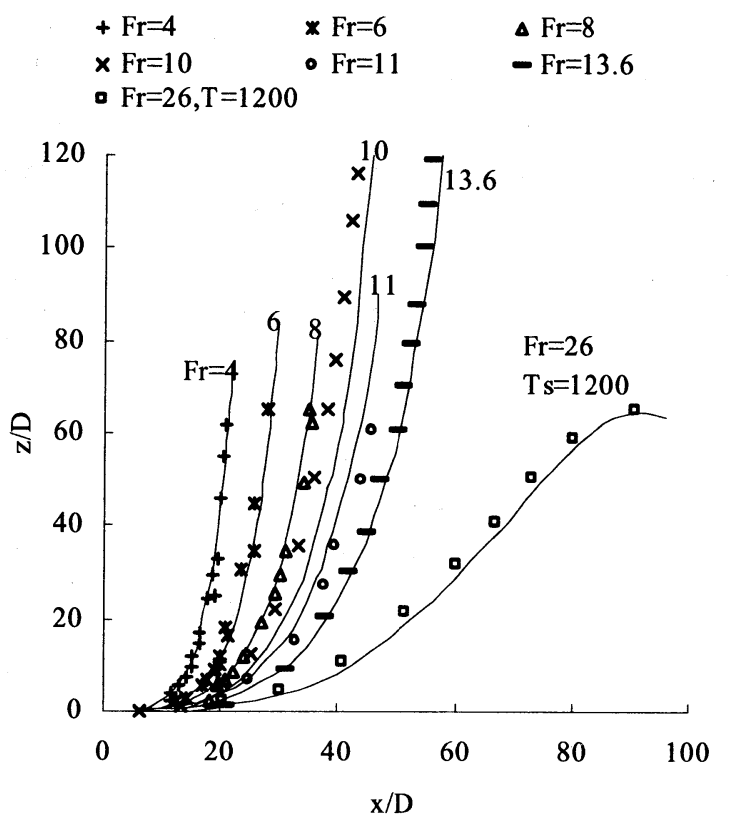

図一 3 静水環境に噴出される密度噴流の中心軸

切片一個の追跡計算で中心軸, 幅, 希䣋度 $\left(\mathrm{S}=\Delta \rho_{0} / \Delta \rho\right)$ などの特性值が求まる．静止環境である ため, 連行係数 $\mathrm{E}_{\mathrm{f}}$ は追跡計算に関与せず， $\mathrm{E}_{\mathrm{s}}$ のみが 必要である. 次元解析により，水平方向密度噴流は 中心軸が $\mathrm{L}_{\mathrm{M}} / \mathrm{L}_{\mathrm{Q}}$ にのみ依存し，上昇高 $\mathrm{H}$ での希釈度 $\mathrm{S}$ は $\mathrm{L}_{\mathrm{M}} / \mathrm{L}_{\mathrm{Q}}$ と $\mathrm{H} / \mathrm{L}_{\mathrm{M}}$ に依存する。ただし，環境流体が密 度成層した場合，中心軸と希釈度は更に密度成層パ ラメー夕 $\mathrm{T}_{\mathrm{s}}=\Delta \rho_{0} /[\mathrm{D}(-\mathrm{d} \rho / \mathrm{d} z)]$ に依存する。ここで, $\mathrm{D}$ は放流口直径である，連行係数 $\mathrm{E}_{\mathrm{s}}$ はモデル自身で算 出できる式(9)を用いて，密度噴流の計算をしてみた。 図一3は予測した密度噴流中心軸と実験值を, 図一 4 は予測した希釈度と Fan\&Brooks ${ }^{1)}$ モデルの計算值 を比較したものである。放流フルード数 $\mathrm{Fr}=\mathrm{U}_{0} /\left(\mathrm{gD} \Delta \rho_{0} / \rho_{0}\right)^{1 / 2}$ は $\mathrm{Fr}=(\pi / 4)^{1 / 4} \mathrm{~L}_{\mathrm{M}} / \mathrm{L}_{\mathrm{Q}}$ でも表すことが できるから，図一 3 は $\mathrm{L}_{\mathrm{M}} / \mathrm{L}_{\mathrm{Q}}$ の変わりに静水環境密度 噴流に多用されるFrで表記している，図一 3 と図-4 から, 本モデルの結果は静水環境において, 実験 データと既存の静水環境モデルによく一致している ことがわかる．流跡を追跡する微分形の連立常微分 方程式(10)は静水環境において，流脈を記述する Fan\&Brooks ${ }^{1)}$ のオイラー型積分モデルとは本質的に 同じで，且つ連行係数 $\mathrm{E}_{\mathrm{s}}$ 多くの実験デー夕から得 られた最適関数であるから，図-3と図一 4 のよう な一致は必然的な結果である.

\section{（2）波の影響を受ける環境}

浅い沿岸水域での密度噴流は波，特に浅海波の影 響を受ける。ここでChin ${ }^{11)}$ の実験をモデル検証に用 いるから，浅海波の起こした流速変化を考える．微 小振幅波理論により, 波による水粒子の運動速度 (図一1参照)は次式で表される：

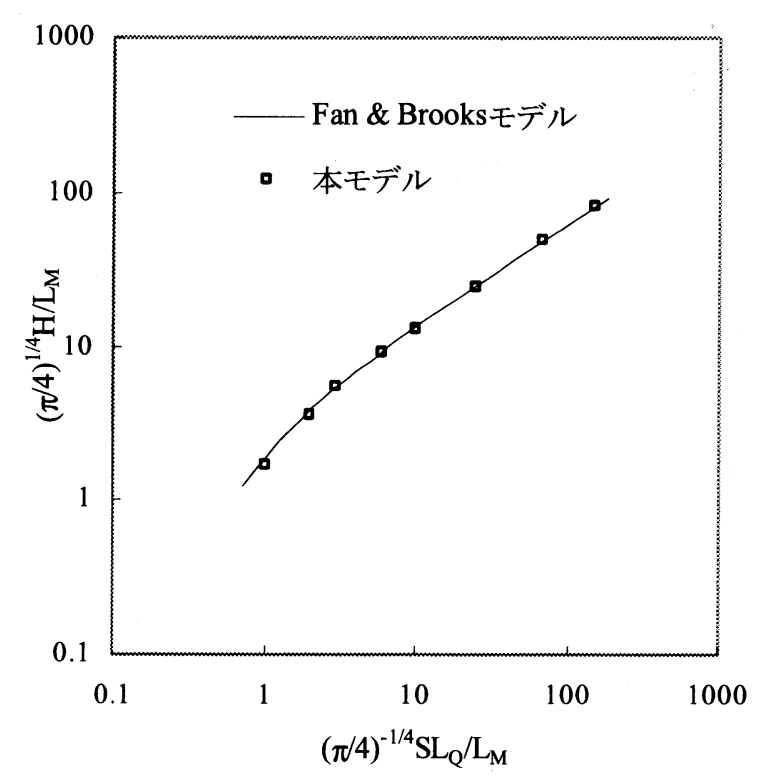

図一4 Fan \& Brooksモデルとの比較

$$
\begin{aligned}
& u^{a}=\frac{a g k}{\sigma} \frac{\cosh (k z)}{\cosh (k h)} \sin (k x-\sigma t) \\
& w^{a}=-\frac{a g k}{\sigma} \frac{\sinh (k z)}{\cosh (k h)} \cos (k x-\sigma t)
\end{aligned}
$$

ここで $\mathrm{k}=2 \pi / \mathrm{L}, \sigma=2 \pi / \mathrm{T}, \mathrm{a}, \mathrm{T}$ とははそれぞれ波の振 幅，周期と波長である。 Chin $^{11)}$ の実験では，放流方 向は水平で，しかも波向に平行している。したがっ て, $\mathrm{y}$ 方向流速がなく, 噴流中心軸は $\mathrm{xz}$ 平面に属す る二次元曲線となる. 波流速の噴流軸に垂直する流 速成分 $\mathrm{U}_{\mathrm{n}}{ }^{\mathrm{a}}$ 上並行する流速成分 $\mathrm{U}_{\mathrm{p}}{ }^{ }$は次式で算出され る：

$$
\begin{aligned}
& \left|U_{n}^{a}\right|=\left|u^{a} \sin \beta-w^{a} \cos \beta\right| \\
& U_{p}^{a}=u^{a} \cos \beta+w^{a} \sin \beta
\end{aligned}
$$

式(10)の数值解を求めるのにあたって, $\mathrm{U}_{\mathrm{n}}{ }^{\mathrm{a}}$ による連 行量 $\Delta \mathrm{V}_{\mathrm{f}}$ を求めるための連行係数 $\mathrm{E}_{\mathrm{f}}$ を決めておく必 要がある. $\mathrm{E}_{\mathrm{f}}$ は実験を最も表現できる最適値として 本研究は

$$
E_{f}= \begin{cases}0.32, & \text { if } \Delta U>u_{\max }^{a} \\ 0, & \text { if } \Delta U \leq u_{\max }^{a}\end{cases}
$$

を用いる，つまり，噴流軸方向流速差 $\Delta U$ U比較的 大きい時に $\mathrm{U}_{\mathrm{n}}{ }^{\mathrm{a}}$ で運動する環境流体の $32 \%$ が密度噴 流に混入するが， $\Delta \mathrm{U}$ は波の最大流速程度に減衰す ると，噴流流体も波に乗って移動するようになって， $\mathrm{U}_{\mathrm{n}}^{\mathrm{a}}$ による周囲流体の混入が無視できる.

流れは非定常であるため, 流脈と流跡は一致しな い. 噴流流体が放流口を出てから水面に達するまで 要する時間の平均を $\mathrm{t}_{\mathrm{s}}$ とすると, 時刻 $\mathrm{t}$ 軌道を得る のに，時刻 $\mathrm{t}-\mathrm{t}_{\mathrm{s}}$ からtまでの間に放出されるすべての 密度噴流流体の流跡計算が必要である。図一 5 は $\mathrm{L}_{\mathrm{M}} / \mathrm{L}_{\mathrm{Q}}=17, \mathrm{~L}_{\mathrm{m}} / \mathrm{L}_{\mathrm{Q}}=21.3, \mathrm{~h} / \mathrm{L}=0.4$ の条件で計算した密 度噴流軌道を示すものである．波は放流口近くで密 

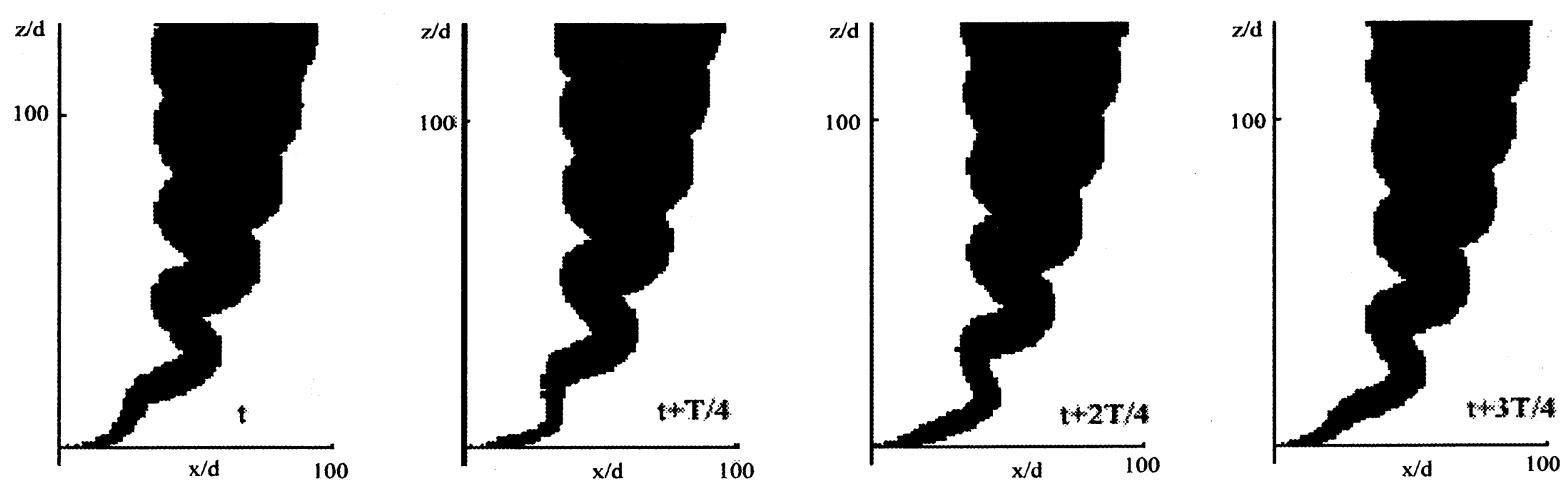

図一 5 計算された密度噴流の軌道

度噴流軌道に与える影響は最も大きいことがわかる。 波流速が放流速度に向かってくる場合, 密度噴流は 比較的近い距離からプルームらしくなって上昇する が, 波流速が放流速度と同じ方向である場合, 密度 噴流は波流流速に乗って比較的長い距離を移動して からプルームらしい動きを示す. 放流口から一定距 離を離れると波に乗って前後動きながら上昇する様 子はどれも似ている。これは $\mathrm{Chin}^{11)} の$ 実験で観測し た運動特性をよく再現している。

$\mathrm{Chin}^{11)}$ の実験で $\mathrm{H} / \mathrm{L}_{\mathrm{M}}=9, \mathrm{~L}_{\mathrm{M}} / \mathrm{L}_{\mathrm{Q}}=17$ と固定されてい るので, 水面での希釈度 $\mathrm{S}$ は次元解析により, $\mathrm{L}_{\mathrm{m}} / \mathrm{L}_{\mathrm{Q}}$ とh/Lに依存する，図一6は本モデルの計算結果と実 験デー夕を比較したものである。実験のばらつきを 考慮に入れると, 計算は非常によく実験に接近して いると言える， $\mathrm{L}_{\mathrm{m}} / \mathrm{L}_{\mathrm{Q}}$ の増大によって, 希釈度は波 のない時の值より，倍近くにも達することが図から 見てわかる。

特筆すべく点はすべての計算において, 連行係数 $\mathrm{E}_{\mathrm{s}}$ と $\mathrm{E}_{\mathrm{f}}$ はそれぞれ式(9)と式(13)にしたがって計算さ れている。すすおち, 放流条件からモデル自身で決 められる。これは放流条件ごとに異なる連行係数を 適用するモデル ${ }^{1), 4}$ に比べ，“予測”というモデル の機能をよりよく達成できる。

\section{(3) モデルの応用}

Chin ${ }^{11)}$ の実験から希釈度 $\mathrm{S}$ は主に $\mathrm{L}_{\mathrm{m}} / \mathrm{L}_{\mathrm{Q}}$ にっって決 定され, $\mathrm{S} / \mathrm{S}_{0}=1+6.15\left(\mathrm{~L}_{\mathrm{Q}} / \mathrm{L}_{\mathrm{m}}\right)$ と近似される。ここで $\mathrm{S}_{0}$ は波がない時の希釈度である. $\mathrm{Chin}^{11)}$ に指摘された ように,この関係は $\mathrm{H} / \mathrm{L}_{\mathrm{M}}=9, \mathrm{~L}_{\mathrm{M}} / \mathrm{L}_{\mathrm{Q}}=17$, 波向に平 行する水平密度噴流を前提条件とする。一方, $\mathrm{S}=8.23\left(\mathrm{~L}_{\mathrm{m}} / \mathrm{L}_{\mathrm{Q}}\right)\left(\mathrm{H} / \mathrm{L}_{\mathrm{M}}\right)^{2}$ で表されるShuto \& $\mathrm{Ti}^{8}{ }^{8}$ の近似式 は, 希釈度 $\mathrm{S}$ が $\left(\mathrm{L}_{\mathrm{m}} / \mathrm{L}_{\mathrm{Q}}\right)$ に比例するところはChin ${ }^{11)}$ と 逆である. 波の働きを分析するとShuto \& $\mathrm{Ti}^{8)}$ の近似 式に疑問点が残る ${ }^{11)}$ が，いずれの近似式も特定条件 下で実験結果を表す数学式であり, たとえ $\mathrm{Chin}^{11)}$ の 式は物理的意味を有しても, 放流条件を変えると使 えなくなるのは一緒である。これに対し，本モデル は近似式ではなく, 理論的に誘導したラングラン
ジュ式に実験から得られた連行係数を加えて, 数值 解を求めている。いわゆる半理論半実験的式である. ラングランジュ式および連行係数のコンセプトを崩 す極端な放流環境でない限り，モデルは有効である. 次に本モデルを用いて，さまざまの放流条件におけ る波の効果を分析する。

放流条件は $\mathrm{h} / \mathrm{L}=0.4$, 波向と放流方向が $\mathrm{x}$ に平行,

$$
\begin{aligned}
& \mathrm{A}: \mathrm{H} / \mathrm{L}_{\mathrm{M}}=18, \mathrm{~L}_{\mathrm{M}} / \mathrm{L}_{\mathrm{Q}}=8.5 ; \\
& \mathrm{B}: \mathrm{H} / \mathrm{L}_{\mathrm{M}}=9, \mathrm{~L}_{M} / \mathrm{L}_{\mathrm{Q}}=17 \text { (Chinの実験) } ; \\
& \mathrm{C}: \mathrm{H} / \mathrm{L}_{\mathrm{M}}=6, \mathrm{~L}_{\mathrm{M}} / \mathrm{L}_{\mathrm{Q}}=25.5 ; \\
& \text { a }: \mathrm{H} / \mathrm{L}_{\mathrm{M}}=19.4, \mathrm{~L}_{\mathrm{M}} / \mathrm{L}_{\mathrm{Q}}=8.5 ; \\
& \text { b }: \mathrm{H} / \mathrm{L}_{\mathrm{M}}=9.7, \mathrm{~L}_{\mathrm{M}} / \mathrm{L}_{\mathrm{Q}}=17 ; \\
& \text { c }: \mathrm{H} / \mathrm{L}_{\mathrm{M}}=6.5, \mathrm{~L}_{\mathrm{M}} / \mathrm{L}_{\mathrm{Q}}=25.5 ;
\end{aligned}
$$

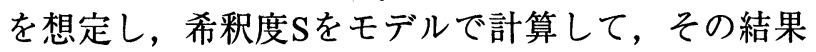
を図一7に示す。これはChin ${ }^{11)}$ 実験への拡張と考え られる. 波の効果を考える際, 希釉度は絶対值 $\mathrm{S}$ 用いるより，波がない時の値 $\mathrm{S}_{0}$ との比 $\mathrm{S} / \mathrm{S}_{0}$ を用いた ほうが理解しやすい。計算結果が示しているように, 同じ波条件の下 $\left(\mathrm{h} / \mathrm{L} と \mathrm{~L}_{\mathrm{Q}} / \mathrm{L}_{\mathrm{m}}\right.$ が一定 $), \mathrm{L}_{\mathrm{M}} / \mathrm{L}_{\mathrm{Q}}$ (つまり 放流フルード数 $\mathrm{Fr})$ が大きければ大きいほど, 波の希 釈度の増大に寄与する効果が大きい ; また, $\mathrm{H} / \mathrm{L}_{\mathrm{M}}$ の 増大にともなって波の効果も増加する。このように， 本モデルを用いて, 実験デー夕のない密度噴流条件 を評価, 予測することができる。

本モデルは波向と放流速度が同じ平面にない放流 環境も評価できると考えられるが, 実験デー夕の欠 そのため，その議論を省くことにする.

\section{4. 結論}

軌道と希釈度にフォーカスを当てて, 波が沿岸水 域での密度噴流に与える影響を, ラングランジュモ デルを用いて評価した. 実験との比較を通して, 本 モデルの有効性が確認された．波の希釈度に寄与す る効果は, $\mathrm{H} / \mathrm{L}_{\mathrm{M}}, \mathrm{L}_{\mathrm{M}} / \mathrm{L}_{\mathrm{Q}}$ と $\mathrm{L}_{\mathrm{Q}} / \mathrm{L}_{\mathrm{m}}$ の増大とともに増加 する特性をモデルで示した.この特性, そして本モ デルによる波効果の定量的評価を利用して, 污水の 

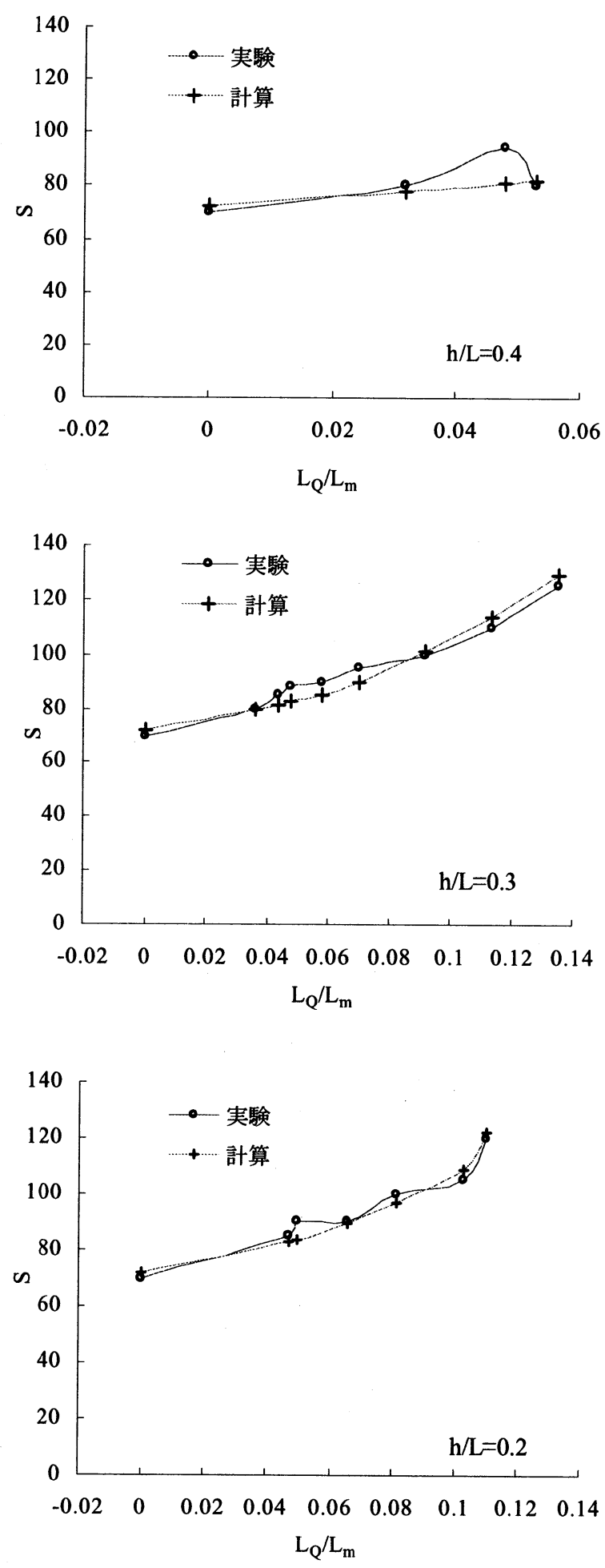

図-6 希釈度の実験と計算の比較

放流設計に際して波を利用した希釈性能の最大化と 建設費の節約が図られる。

\section{参考文献}

1) Fan, L. N., and Brooks, N. H.: Numerical solutions of turbulent buoyant jet problems, Report No. KH-R-18, Calif. Inst. of

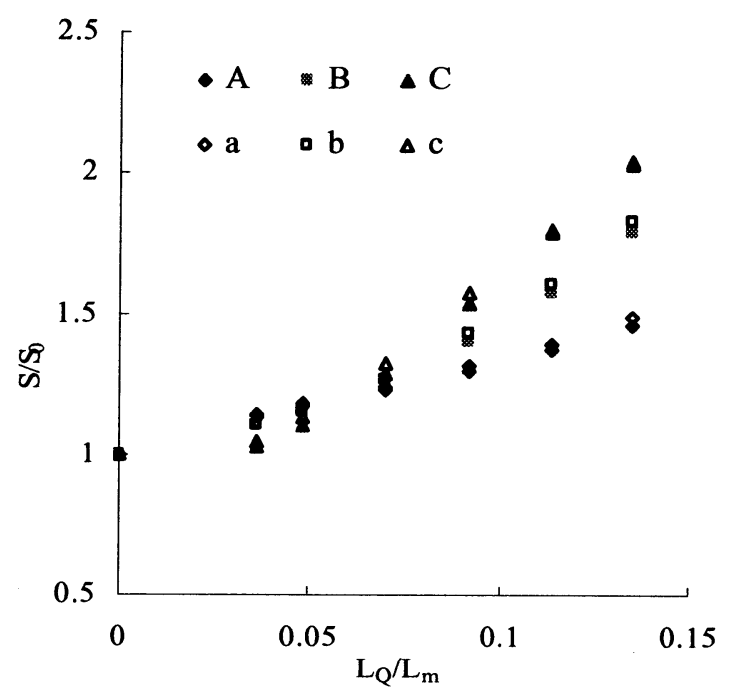

図一7 計算された稀釈度

Technology, Pasadena, Calif., 1969.

2) Fischer, H. B.: Mixing in inland and coastal waters, Academic Press, New York, N. Y.

3) Lee, J. H. W., and Cheung, V.: Generalized Lagrangian model for buoyant jets in current, J. Envir. Engrg., ASCE, Vol.116(6), pp.1085-1106, 1990.

4) Bemporad, G. A.: Simulation of round buoyant jet in stratified flowing environment, J. Hydr. Engrg., ASCE, Vol.120(5), pp.529-543, 1994.

5) 楊宏選, 早川典生, 福島裕介: 非一様流れ場における密 度噴流，水工学論文集, Vol.43, pp.929-934, 1999.

6) Agg, A. R., and Wakeford, A. C.: Field studies of jet dilution of sewage at sea outfalls, Inst. of Public Health Engineers Journal, Vol. 71, pp.126-149, 1972.

7) Hendricks, T. J.: In-situ measurements of initial dilution, Southern California Coastal Research Project Report, pp.41-51, 1977.

8) Shuto, N. and Ti, L. H.: Wave effects on buoyant plumes, Proc. $14^{\text {th }}$ Coastal Engrg. Conf., pp.2199-2209, 1974.

9) Ger, A. M.: Wave effects on submerged buoyanyt jets, Proc. $8^{\text {th }}$ Congress. Int. Assoc. Hydr. Res., pp.295-300, 1979.

10) Ismail, N. M., and Wiegel, R. L.: Opposing wave effect on momentum jets spreading rate, J. Waterway, Port, Coastal ang Ocean Engrg., ASCE, Vol.109(4), pp.465-483, 1983.

11) Chin, D. A.: Influence of surface waves on outfall dilution, J. Hydr. Engrg., ASCE, Vol.115(8), pp.1007-1018, 1987.

12) 楊宏選と早川典生: 流向が反転する流れに放出される密度 噴流の積分モデル, 水工学論文集, Vol.47,pp.1135-1140, 2003.

13) Lee, J. H. W., and Neville-Jones, P.: Initial dilution of horizontal jet in crossflow, J. Hydr. Engrg., ASCE, Vol.113(5), pp.615-629, 1987.

（2003.9.30受付） 